\title{
Selenium in reproductive health
}

Hiten D. Mistry $\mathrm{PhD}^{1}$, Fiona Broughton Pipkin DPhil ${ }^{2}$, Christopher W. G. Redman $\mathrm{MD}^{3}$ \& Lucilla Poston $\mathrm{PhD}^{1}$

London, Nottingham and Oxford, United Kingdom

${ }^{1}$ Maternal and Fetal Research Unit, Division of Women's Health, King's College London, London, SE1

7EH, UK; ${ }^{2}$ School of Clinical Sciences, Department of Obstetrics \& Gynaecology, University of Nottingham, Nottingham, NG5 1PB, UK; ${ }^{3}$ Nuffield Department of Obstetrics and Gynaecology, University of Oxford, John Radcliffe Hospital, Oxford, OX3 9DU, UK.

Correspondence name \& address: Dr. Hiten D. Mistry

Maternal and Fetal Research Unit

Division of Women's Health

King's College London

St Thomas' Hospital

Westminster Bridge Road

London, UK

SE1 7EH

Tel: $+44(0) 2071888151$

Fax: +44(0)20 76201227

Email: hiten.mistry@kcl.ac.uk

Financial Support: Part of the work cited in this manuscript was supported by Tommy's Charity (registered charity no. 1060508) as is HDM and The Biotechnology and Biological Sciences Research Council (BBSRC, UK).

Word count: Abstract: 161; Main Text: 5,777. 
1 This is a topical review summarising the increasing evidence for an association between

2 inadequate dietary antioxidant selenium intake and several disorders of reproduction.

4 Short Title: Selenium in reproductive Health

5

6 


\section{Abstract}

25 Hiten D. Mistry $\mathrm{PhD}^{1}$, Fiona Broughton Pipkin DPhil ${ }^{2}$, Christopher W. G. Redman MD ${ }^{3}$

26 \& Lucilla Poston $\mathrm{PhD}^{1}$

28 Selenium is an essential trace element of importance to human biology and health.

29 Increasing evidence suggests that this mineral plays an important role in normal growth

30 and reproduction in animals and humans, and selenium supplementation is now

31 recommended as part of public health policy in geographical areas with severe selenium

32 deficiency in soil. Here, the biological functions of selenium are addressed prior to a

33 detailed review of associations between selenium status and reproductive health. In many

34 countries, selenium dietary intake falls below the recommended nutrient intakes (RNIs)

35 and is inadequate to support maximal expression of the selenoenzymes. Numerous reports

36 implicate selenium deficiency in several reproductive and obstetric complications

37 including male and female infertility, miscarriage, pre-eclampsia, fetal growth restriction,

38 preterm labour, gestational diabetes and obstetric cholestasis. Currently, there is

39 inadequate information from the available small intervention studies to inform public

40 health strategies. Larger intervention trials are required to reinforce or refute a beneficial

41 role of selenium supplementation in disorders of reproductive health.

43 Keywords: Antioxidant, pregnancy, reproduction, selenium 


\section{$47 \quad$ Introduction}

48 Selenium was first discovered in 1817 by Jöns Jacob Berzelius when investigating the

49 chemicals responsible for outbreaks of ill health amongst workers in a Swedish sulphuric

50 acid plant, which had switched from expensive, imported sulphur to a local product

51 (Oldfield, 1987). The local product contained a contaminant which he named Selēnē,

52 after the Greek goddess of the moon (McKenzie et al., 1998). Selenium lies directly

53 below sulphur in the periodic table and above tellurium, and has similar chemical

54 properties, as it binds with equal affinity to metals and non-metals, both directly and

55 hydrochemically (Bauer, 1997, Burk and Levander, 2006). In 1957, Klaus Schwarz

56 proved that selenium is an essential nutrient necessary for both normal growth and

57 reproduction in animals through experiments demonstrating that minute amounts of

58 selenium were protective against a form of liver necrosis in laboratory rats fed diets

59 containing torula yeast as a protein source (Schwarz and Foltz, 1957). Dietary

60 supplementation, by means of selenium-enriched fertilizer in crop production, foliar

61 spraying of staple crops such as rice or soya beans or, directly, through multi-vitamin

62 supplementation is now an accepted practice in areas of selenium deficiency, worldwide

63 (Oldfield, 2002, Yang et al., 1988).

65 Selenium, amino acids and selenoproteins

66 The amino acids methionine and cysteine contain sulphur in the form of thiol groups.

67 Selenium can replace the sulphur to form selenomethionine ([Se]Met) or selenocysteine

68 ([Se]Cys or $\mathrm{Sec}$ ) as a normal physiological process. A selenoprotein is any protein that

69 includes a Sec or [Se]Met residue, which confers specific biological function. Dietary 
70 selenium, initially taken up from the soil and concentrated by plants, is absorbed in the

71 small intestine and incorporated into proteins by complex mechanisms which remain

72 unclear (Reilly, 2006). The majority of selenium in the human diet is derived from

73 [Se]Met in plant materials and both [Se]Met and Sec in animal products (Combs, 2001,

74 Sunde, 1990). [Se]Met cannot be synthesised by higher animals, including humans, but

75 after ingestion is non-specifically incorporated into proteins (e.g. haemoglobin, albumin)

76 in place of methionine (Thomson et al., 1993). Selenophosphate is synthesised from

77 selenide and ATP through the action of selenophosphate synthetase 2 (SEPHS2) and is

78 the source of selenium from which Sec is then formed and co-translationally incorporated

79 into selenoproteins at in-frame UGA codons. Sec has a lower $\mathrm{p} K_{a}$ than Cys and is more

80 nucleophilic, so is more reactive. During protein catabolism, Sec is rapidly broken down

81 to elemental selenium, leaving no free pool of cellular Sec. This has a biological

82 advantage, since Sec can react with oxygen, thioredoxin and thioredoxin reductase,

83 giving rise to rapid NADPH oxidation and the formation of damaging reactive oxygen

84 species (ROS) (Lu and Holmgren, 2009).

86 The form in which selenium is present in food affects bioavailability and expression of

87 the different selenoproteins. Organic selenium sources such as Se[Met] are more efficient

88 at increasing the blood selenium concentration than inorganic selenium, such as selenite

89 and selenate, but they appear to be equally adept at raising whole-blood glutathione

90 peroxidase (GPx) activity in the long-term (Thomson et al., 1993). Bioavailability from

91 the different selenium sources is also tissue dependent. Dietary protein is more effective

92 than other sources in increasing measurable selenium status. High selenium consumption 
93 leads to higher selenium content of proteins in the form of [Se]Met and Sec (Kohrle et al., 94 2005).

96 Selenite $\left(\mathrm{SeO}_{3}{ }^{2-}\right.$; inorganic form of selenium) crosses the plasma membrane, and reacts

97 with cytoplasmic thiols in the reduction pathway; this forms selenide, which is then

98 methylated, giving rise to methylated selenium derivatives that are excreted in urine, in

99 expired air via the lungs and in faeces (Fig. 1) (Sunde, 1990, Ip, 1998). In humans these

100 products of selenium metabolism are predominantly excreted in urine (Yang et al., 1989,

101 Oster and Prellwitz, 1990). The proportion of selenium intake excreted in this manner

102 depends on dietary intakes; when this is high, urinary excretion will also be high and vice

103 versa (Robinson et al., 1973, Thomson and Robinson, 1986, Oster and Prellwitz, 1990).

105 There appears to be no homeostatic control of selenium absorption, which is unusual, in 106 contrast, for example, to the complex regulation of iodine absorption (Kohrle et al., 2005,

107 Reilly, 2006, Fairweather-Tait et al., 2010). Selenium is stored in the tissues in varying

108 density: $30 \%$ in the liver, $30 \%$ in muscle, $15 \%$ in the kidney, $10 \%$ in the plasma, and the

109 remaining $15 \%$ throughout other organs (Levander, 1987, Reilly, 2006). Concentrations

110 of free selenium are greatest in the renal cortex and pituitary gland, followed by the

111 thyroid gland, adrenals, testes, ovaries, liver, spleen, and cerebral cortex (Drasch et al.,

112 2000, Kohrle et al., 2005).

113

114 Selenoproteins, coded by twenty five selenoprotein genes in humans (Table 1) (Kryukov 115 et al., 2003), exert multiple actions on endocrine, immune and inflammatory functions 
116 (Beckett and Arthur, 2005, Thomson, 2004), in part because they have powerful

117 antioxidant functions. The selenoenzymes have a Sec group at their active sites, which

118 enables the formation of disulphide bonds (Burk and Levander, 2006); these function as a

119 redox centre, participating in transfer of electrons between molecules (Flohe et al., 2000).

120 Of the identified selenoproteins, three are iodothyronine deiodinases, which catalyse the

121 removal of iodine from the 5 or 5 ' positions of iodothyronine substrates. This regulates

122 the activation and inactivation of thyroid hormones in all tissues (Beckett and Arthur,

123 2005). A further three are the thioredoxin reductase family (TrxR1, TrxR2 and TrxR3).

124 Their substrates, thioredoxin and thioredoxin peroxidase do not contain selenium. These

125 constitute a powerful dithiol-disulphide system that regulates the cellular redox state (Hill

126 et al., 2003, Burk et al., 2003, Mostert et al., 2003) (Table 1). The Trx system also

127 regulates other antioxidants (such as heme oxygenase-1, methionine sulphoxide

128 reductases, ascorbate (Vit C), tocopherol (Vit E), ubiquinone (Q10)), modulates several

129 transcription factors (eg those involved in the maturation of p53) and regulates apoptosis

130 and protein phosphorylation (Surai, 2006, Arner, 2009, Mostert et al., 2003).

132 Of particular importance to reproduction and pregnancy are the 6 antioxidant GPxs which

133 play a pivotal role in reducing hydrogen peroxide $\left(\mathrm{H}_{2} \mathrm{O}_{2}\right)$ and lipid peroxides to harmless

134 products (water and alcohols; Fig. 2), thereby dampening the propagation of damaging

135 ROS (Rotruck et al., 1973, Brigelius-Flohe et al., 2003). This important pathway of

136 cellular protection has been demonstrated in all mammalian tissue examined (Allan et al.,

137 1999, Knapen et al., 1999). As antioxidants, the GPxs help maintain membrane integrity,

138 protect prostacylin production, and limit the propagation of oxidative damage to lipids, 
139 lipoproteins, and DNA (Brigelius-Flohe et al., 2003). This pathway may also offer

140 protection against development of several chronic diseases in which oxidative damage

141 has been implicated, including atherosclerosis and certain cancers (Rayman, 2002,

142 Combs, 2001, Brigelius-Flohe, 2008). However, the claims that selenium supplements

143 contribute to the prevention of chronic disease currently lack substantial evidence based

144 proof of efficacy. Indeed some of the larger trials have been negative, for example the

145 recent randomised, placebo-controlled cancer chemoprevention trial (selenium and

146 vitamin E cancer prevention trial; SELECT) demonstrated no benefit of supplements of

147 selenium $(200 \mu /$ day $)$ and vitamin E (400 IU/day) in prevention of prostate cancer in a

148 total of 35,533 men (Lippman et al., 2009).

150 Dietary selenium

151 Plant foods are the major dietary sources of selenium in most countries (Rayman, 2000,

152 Combs, 2001). Surveys suggest that wheat is the most efficient selenium accumulator of

153 the common cereals, and is one of the most important selenium sources for man (Lyons et

154 al., 2003, Reilly, 2006). The content in food depends on the selenium content of the soil

155 where plants are grown or animals are raised. For example, the selenium content in the

156 soil of the high plains of northern Nebraska and the Dakotas is very high, and the

157 inhabitants have the highest selenium intakes in the US (Longnecker et al., 1991).

158 Whether this degree of high intake has any positive health benefit is not known, but toxic

159 effects supervene when intake exceeds $850 \mu \mathrm{g} /$ day (Goldhaber, 2003). 
161 Other foods make a substantial contribution to selenium intake in northern Europe,

162 particularly meat, poultry, and fish (a total of about $36 \%$ in the UK) (Ministry Of

163 Agriculture Fisheries and Food, 1997). Thus it has been predicted that vegetarians or

164 vegans are at specific risk of selenium deficiency (Reilly, 2006, Judd et al., 1997), but

165 this claim is not fully substantiated.

166

167 Selenium incorporation into plants (initially), and then into animal tissues, not only

168 depends on soil selenium content or geochemistry but also on soil $\mathrm{pH}$, rainfall, land

169 contour, the use of high-sulphur fertilisers and microbial activity; some bacteria can

170 convert insoluble forms of selenium to soluble forms, which can then be taken up by

171 plants (Diplock, 1993, Lyons et al., 2003). Selenium tends to be more concentrated in the

172 soils of the drier regions of the world, where soil tends to be more alkaline; in acidic

173 poorly aerated soils, selenium is relatively unavailable to plants as it is present mainly as

174 insoluble selenite complexes (Lyons et al., 2003, Reilly, 2006).

175

176 In addition, in wetter regions, rain leaches selenium from the soil (Reilly, 2006).

177 Selenium forms both inorganic and organic compounds and can be an oxidant as well as a

178 reductant, an important factor in soil formation (Van Dorst and Peterson, 1984).

179 Selenium's chemical adaptability accounts for its widespread occurrence in soils, plants,

180 animals and humans (Bauer, 1997). Soil selenium concentrations range from 0.1 to more

181 than $100 \mathrm{mg} / \mathrm{Kg}$. However, most soils contain between 1.0 to $1.5 \mathrm{mg} / \mathrm{Kg}(0.1-0.6 \mathrm{mg} / \mathrm{Kg}$

182 is considered deficient) (Lyons et al., 2003, Combs, 2001). 
185 The optimal range of selenium intake to ensure biological benefit appears to be narrow

186 and has still not been determined with certainty; however selenium deficiency has been

187 studied in animals and humans (Van Vleet, 1980, Zachara et al., 1993a, Hurst et al.,

188 2010). Selenium deficiency as assessed by dietary intake and/or blood selenium

189 concentrations has been identified in people inhabiting geographical regions notable for

190 low soil selenium content, such as volcanic regions and in Finland and New Zealand,

191 where the reported average selenium intake is approximately 30-40 $\mu \mathrm{g} /$ day (Levander and

192 Burk, 1994, Thomson, 2004). Animal selenium deficiency diseases have been routinely

193 identified since the 1950s in livestock in countries that have low selenium soil conditions

194 (Oldfield, 1997, Koller and Exon, 1986).

196 Human selenium deficiency diseases have been recognised in China and Tibet (Moreno-

197 Reyes et al., 2003, Levander and Beck, 1997). Keshan disease, a reversible endemic

198 cardiomyopathy, is characterised by focal myocardial necrosis often associated with

199 inflammatory infiltrates and calcification. The disorder is exclusively endemic in

200 selenium-deficient rural areas of China e.g. Keshan (Beck et al., 2003) and

201 supplementation with selenium tablets (as sodium selenite) in pregnancy (Moore et al.,

202 2000) provides highly effective protection against its development in susceptible women

203 (Beck et al., 2003).

205 In Northern Karelia (Finland) very low blood selenium concentrations have also been 206 reported in men with a high risk of myocardial infarction (MTT Agrifood Research 
207 Finland, 2005). Smoking further compromises selenium status by decreasing the serum

208 concentration of selenium, and erythrocyte GPx activity (Northrop-Clewes and

209 Thurnham, 2007, Duthie et al., 1993). Low selenium status may exacerbate disease

210 progression in conditions not otherwise associated with selenium-deficiency e.g. human

211 immunodeficiency virus (HIV) infection and hepatitis C virus, although the mechanism

212 which affords protection by selenium is not known (Rayman, 2000).

214 Dietary selenium intake in most parts of Europe is considerably lower than in the USA,

215 mainly due to the European soils providing a poorer source of selenium (Thomson, 2004,

216 Rayman, 2008). The reduction in consumption of wheat imported from the US in the

217 European Union from the 1980s, as a result of the European Common Agricultural

218 Policy, has been associated with a fall in daily selenium intake in the UK and other

219 Western European countries over the last 20 years (Jackson et al., 2004).

221 Assessments of requirements, adequacy and intakes of selenium have been reviewed

222 previously in detail (Rayman, 2008, Thomson, 2004). The recommended daily

223 allowances (RDA) for both men and women in USA is $55 \mu \mathrm{g} / \mathrm{day}$, rising to $60 \mu \mathrm{g} / \mathrm{day}$ for

224 pregnant women (Institute of Medicine, 2000). The UK is still using the 1991 reference

225 nutrient intakes (RNI) of $75 \mu \mathrm{g} /$ day for adult men, $60 \mu \mathrm{g} /$ day for adult women and 75

$226 \mu \mathrm{g} /$ day for lactating women (Department of Health, 1991). The Department of Health

227 reviewed whether selenium intake should be higher in 1998 and then again in 2009, but

228 concluded that the original figures were still applicable (Department of Health, 1998,

229 Department of Health, 2009). The World Health Organisation (WHO) set its normative 
230 requirement estimate (NR) at a lower value of $40 \mu \mathrm{g} / \mathrm{day}$ for men and $30 \mu \mathrm{g} / \mathrm{day}$ for

231 women (WHO/FAO/IAEA, 1996). The RDA/RNI values have been determined from the

232 intake believed necessary to maximise the activity of the antioxidant GPx in plasma,

233 whereas the NR is based on selenium intake needed to achieve two-thirds of maximum

234 activity of erythrocyte GPx (Thomson, 2004).

235

236 Selenium intake appears on average to be at or above the RDA in the US or Canada. A

237 study in Maryland in 1981 reported that adults consumed an average of $81 \mu \mathrm{g} /$ day of

238 selenium (Welsh et al., 1981) and recently this has been estimated to be $108 \mu \mathrm{g} /$ day for

239 all US adults and $89 \mu \mathrm{g} /$ day for women (Chun et al., 2010). A Canadian survey in 1975

240 reported intakes of 113 to $220 \mu \mathrm{g} /$ day (Thompson et al., 1975); this was followed in 1998

241 by a report indicating consumption of between 98-224 $\mu \mathrm{g} /$ day (Gissel-Nielsen, 1998).

242 Conversely, the UK selenium dietary intake is generally below the RNI; a dietary survey

243 published by the UK Government over the period 1994 to 1995 indicated that the average

244 intake was as low as 30-40 $\mu \mathrm{g}$ per day (Ministry Of Agriculture Fisheries and Food,

245 1997) a figure which had not improved in a survey conducted between 2008 and 2009

246 (Department of Health, 2009). Although it has been argued that UK intakes are

247 sufficiently low to warrant government intervention (Rayman, 2000), a UK government

248 expert committee concluded in 1998 that intervention was, at that time, not warranted

249 (Department of Health, 1998). Whether, this conclusion pertains to the dietary intake in

2502010 is uncertain and is worthy of investigation.

251 Selenium toxicity 
252 Whilst selenium deficiency is prevalent and therefore the more predominant health issue,

253 there is also a moderate to high health risk of selenium toxicity, first discovered in

254 animals grazing in areas with high selenium content in the soil (Twomey et al., 1977).

255 Chronic toxicity of selenium in humans results in selenosis, a condition characterised by

256 brittleness or loss of hair and nail loss, gastrointestinal problems, rashes, garlic breath

257 odour, and nervous system abnormalities (Yang et al., 1983). In China, it has been

258 reported that selenosis occurs with increased frequency in people who consumed

259 selenium at levels above $850 \mu \mathrm{g} /$ day (Yang and Zhou, 1994). The Institute of Medicine,

260 USA, has set a tolerable upper intake level for selenium at $400 \mu \mathrm{g} / \mathrm{day}$ for adults to

261 prevent the risk of developing selenosis (Institute of Medicine, 2000). The European

262 Commission and WHO have proposed the lower daily upper limit of $300 \mu \mathrm{g} / \mathrm{day}$ for

263 adults (European Commission Health and Consumer Protection Directorate, 2000,

264 WHO/FAO/IAEA, 1996).

265

266 Selenium in Reproductive Health

267 The role that selenium plays in both male and female reproduction is well recognised in 268 animal husbandry (Reilly, 2006). Selenium is essential for male fertility, being required

269 for testosterone biosynthesis and the formation and normal development of spermatozoa

270 (Behne et al., 1996, Flohe, 2007). Studies using selenoprotein P-knockout mice support a

271 requirement for selenium in testicular function (Hill et al., 2003) and animals fed

272 selenium-deficient diets show impaired spermatozoan motility with flagellar defects

273 localised primarily to the midpiece, decreasing the chance of fertilisation (Behne et al.,

274 1996, Wu et al., 1973). 
276 Testicular tissue contains high concentrations of selenium, predominantly as GPx4 and

277 this provides the pivotal link between selenium, sperm quality and male fertility since

278 GPx4 is a fundamental determinant of the architecture of the spermatozoan midpiece

279 (Beckett and Arthur, 2005, Knapen et al., 1999), and is considered to shield developing

280 sperm cells from oxidative DNA damage (Ursini et al., 1999, Safarinejad and Safarinejad,

281 2009). ROS have been implicated in male infertility because, through attack of the

282 spermatozoa membrane, sperm viability is decreased.

283

284 Some evidence suggests that increasing selenium dietary intake increases antioxidant

285 GPx activity, thereby increasing male fertility (Irvine, 1996). Bleau et al's study in 1984

286 was one of the first indications, in humans, that selenium deficiency may be related to

287 male fertility, reporting an optimal range between $50-60 \mu \mathrm{g} / \mathrm{ml}$ in semen and a positive

288 correlation between sperm count and semen selenium concentration in 125 men from

289 couples being investigated for infertility (Bleau et al., 1984). In Scotland (where mean

290 selenium intakes are below requirements, $\sim 30-40 \mu \mathrm{g}$ per day) a placebo-controlled

291 randomised control trial (RCT) of 64 men demonstrated that sperm quality and fertility

292 improved after selenium supplementation (Scott et al., 1998). A placebo-controlled RCT

293 from Tunisia of 54 infertile and 54 men on placebo also demonstrated the beneficial

294 effects of a combination of vitamin E (400 mg) and selenium (225 $\mu \mathrm{g})$ daily supplements

295 for 3 months on improving sperm motility (Keskes-Ammar et al., 2003). In another recent

296 placebo-controlled RCT in Iran of 468 infertile men, supplementation with $200 \mu \mathrm{g}$

297 selenium orally daily for 26 weeks improved semen quality including sperm count, 
298 concentration, morphology and motility, as well as plasma and semen selenium

299 concentrations (Safarinejad and Safarinejad, 2009). A recent review of the effect of oral

300 antioxidants (including selenium) on male subfertility concluded that supplementation

301 could improve sperm quality and/or pregnancy rates but recommended that large

302 adequately powered trials using individual antioxidants are required (Ross et al., 2010).

304 Data regarding selenium and female fertility are sparse. Paszkowski et al, completed a

305 study of 135 follicular fluid samples collected from 115 patients during transvaginal

306 oocyte retrieval; patients with unexplained infertility had significantly decreased

307 follicular selenium concentrations compared to those with tubal infertility or a known

308 male related cause of infertility (Paszkowski et al., 1995). A recent case-controlled study

309 from Turkey also found lower serum and follicular fluid selenium concentrations in 30

310 women undergoing IVF treatment compared to 13 age-matched non-pregnant control

311 women (Ozkaya et al., 2010). Another rather indirect indication of a role for selenium in

312 fertility comes from a small study of women with a history of unexplained infertility. In 6

313 of the 12 women investigated the red-cell magnesium content failed to normalises after 4

314 months of magnesium supplementation and was associated with a lower red-cell GPx

315 activity than that observed in the remaining 6 women whose red-cell magnesium regained

316 normality (Howard et al., 1994). Subsequent supplementation with magnesium and

317 selenium for 2 months achieved red-cell magnesium normalisation and increased red-cell

318 GPx activity and the women later (within 8 months) conceived with a healthy pregnancy

319 outcome (Howard et al., 1994). The authors theorised that failure to maintain cellular 
320 magnesium homeostasis result from ROS induced cell permeability secondary to poor

321 selenium status (Howard et al., 1994).

322

323 A combination of insulin, transferrin and selenium (ITS) is widely used as an adjuvant

324 mixture in culture media for studies of ovarian and early pregnancy tissue, including

325 human pre-antral follicles (Roy and Treacy, 1993, Abedelahi et al., 2010) or human fetal

326 ovaries (Roig et al., 2006). The addition of selenium is reported to increase total

327 antioxidant capacity and GPx activity, and decrease the levels of ROS, thus improving

328 the in vitro development of follicles (Abedelahi et al., 2010).

330 In reinforcing the antioxidant properties of selenium, these studies highlight a potential

331 role in female reproductive function. As concluded in a recent review, the relationship

332 between oxidative stress, decreased female fertility, and selenium deficiency is an

333 association which warrants further research activity (Ruder et al., 2009).

335 Selenium and disorders of pregnancy

336 Miscarriage

337 Miscarriage, a clinically detectable pregnancy that fails to progress past 24 weeks'

338 gestation, occurs in 10-20\% of all pregnancies (Bradley and Hamilton-Fairley, 1998).

339 Genetic (chromosomal) abnormalities explain at least half of all miscarriages. Although

340 anatomical, endocrine, immune, infective and thrombophilic conditions are other possible

341 causes, most chromosomally normal miscarriages remain unexplained or idiopathic

342 (Hirschfeld et al., 2007). 
344 Miscarriages have been associated with selenium deficiency in veterinary practice (Stuart

345 and Oehme, 1982), and selenium supplements prevent early pregnancy loss in sheep

346 (Hidiroglou, 1979). In humans, a UK observational study reported significantly lower

347 serum selenium concentrations in 40 women with $1^{\text {st }}$ trimester miscarriage compared to

34840 age-matched non-pregnant and 40 healthy gestation-matched women (Barrington et

349 al., 1996). A similar finding was reported in another observational study from Turkey of

35020 women with $1^{\text {st }}$ trimester miscarriage compared to controls (Kocak et al., 1999). Red-

351 cell and hair selenium concentrations are also reported to be lower in women with

352 recurrent miscarriage (Al-Kunani et al., 2001, Kumar et al., 2002). Early pregnancy loss

353 has been linked to reduced antioxidant protection of biological membranes and DNA and

354 also to low concentrations of the selenium-dependent GPx (Barrington et al., 1997,

355 Zachara et al., 2001, Jauniaux et al., 2006), and although speculative, women with

356 recurrent pregnancy loss could potentially benefit from optimisation of selenium status.

$358 \quad$ Normal Pregnancy

359 During normal pregnancy, the selenium requirement is increased as a result of demands

360 from the growing fetus (Smith and Picciano, 1986) and both inorganic and organic forms

361 of selenium cross the placenta in humans and experimental animals (Shennan, 1987,

362 Shennan, 1988, Nandakumaran et al., 2003, Nandakumaran et al., 2002). The RDA of

363 selenium in pregnancy in the USA, calculated based on a fetal deposition of $4 \mu \mathrm{g} /$ day

364 throughout pregnancy, is $60 \mu \mathrm{g} /$ day (Institute of Medicine, 2000). 
366 In countries such as Poland and Yugoslavia where soil selenium content and dietary

367 intake are low, maternal selenium concentrations and GPx activity fall during pregnancy,

368 being the lowest at delivery compared with non-pregnant controls (Mihailovic et al.,

369 2000, Zachara et al., 1993b). In contrast, in areas of very high soil selenium content e.g.

370 South Dakota, it would appear that there is no gestational trend in serum selenium

371 concentrations (Kundu et al., 1985). Babies generally have lower selenium concentrations

372 compared to the mother (Gathwala et al., 2000, Mistry et al., 2008), which might be

373 anticipated as selenium is transported via the placenta across a concentration gradient via

374 an anion exchange pathway, (Shennan, 1987, Shennan, 1988).

377 Pre-eclampsia

378 Pre-eclampsia (de novo proteinuric hypertension) is estimated to occur in $\sim 3 \%$ of all

379 pregnancies and is a leading cause of maternal and perinatal mortality and morbidity in

380 the Western world (Sibai et al., 2005, Steegers et al., 2010); together with other

381 hypertensive disorders of pregnancy, pre-eclampsia is responsible for approximately

38260,000 maternal deaths each year (Broughton Pipkin, 2001) and increases perinatal

383 mortality five-fold (Roberts and Lain, 2002). Optimal outcome for the mother and child

384 often dictates that the infant is delivered early leading to increased preterm delivery and

385 low infant birthweight rates. Placental and maternal systemic oxidative stress are

386 components of the syndrome (Poston, 2004) and contribute to a generalised maternal

387 systemic inflammatory activation (Redman and Sargent, 2003). Placental ischaemia- 
388 reperfusion injury has been implicated in excessive production of ROS, causing release of

389 placental factors that mediate the inflammatory responses (Hung and Burton, 2006).

391 Endothelial cell dysfunction has been implicated in the many clinical manifestations of

392 pre-eclampsia including hypertension and altered haemodynamics (Hubel, 1999, Poston,

393 2006). There is increased interest in the association between selenium status and pre-

394 eclampsia. In light of the association between oxidative stress and the prevalence of low

395 dietary selenium status worldwide, several studies have suggested that selenium

396 deficiency may be linked to pre-eclampsia.

398 The recent appreciation that nutrient-gene interactions may play a major role in 399 manifestation of hereditary disease traits (Hesketh, 2008) could be of relevance to the

400 association between selenium status and pre-eclampsia. Several genes which encode

401 selenoproteins demonstrate functional polymorphisms. Examples include GPx3,

402 functional polymorphisms of which decrease transcriptional activation, gene expression

403 and plasma protein activities (Voetsch et al., 2007a, Voetsch et al., 2007b). A single

404 nucleotide polymorphism within the 3'UTR of the GPx4 gene (GPx4c718t) affects GPx

405 protein concentration and activity but also has differential effects on GPx3 and GPx1

406 when selenium supplementation is stopped (Meplan et al., 2008).

408 Selenoprotein S (also known as SEPS1 or VIMP), which contains a Sec residue at its 409 active site, is an anti-inflammatory protein that acts primarily to limit the damaging 410 consequences of endoplasmic reticulum stress (Ye et al., 2004), which has recently been 
411 suggested to contribute to the development of pre-eclampsia (Burton et al., 2009). A

412 polymorphic variant in the SEPS1 locus has been associated with increased

413 cardiovascular disease morbidity in Finnish females (Alanne et al., 2007) and a 105G>A

414 promoter polymorphism associated with reduced function has been defined and is

415 significantly but not strongly associated with pre-eclampsia (Moses et al., 2008). Given

416 that pre-eclampsia has a familial component (Cincotta and Brennecke, 1998, Lie et al.,

417 1998, Chappell and Morgan, 2006), a high prevalence of these polymorphisms could, in

418 association with selenium deficiency be a major determinant of impaired antioxidant

419 defence in this disorder, through altered selenoprotein activity, and thereby contribute to

420 development of the disease through 'nutrigenomic' pathways. Genome wide association

421 studies of adequate size, such as that currently underway (Wellcome Trust case-control

422 consortium (WTCCC3) - pre-eclampsia;

423 http://www.wtccc.org.uk/ccc3/projects/ccc3_eclampsia.shtml) will be valuable in

424 determination of the prevalence of these and similar functional polymorphisms in women

425 affected by pre-eclampsia.

426

427 In the UK, where selenium dietary intake is low, our group and others have reported

428 selenium concentrations in pre-eclamptic pregnancies to be reduced in sera from the

429 mother (Atamer et al., 2005, Mistry et al., 2008) and fetus (Mistry et al., 2008) as well as

430 in amniotic fluid (Dawson et al., 1999) and in toenails (reflecting longer term selenium

431 stores) (Rayman et al., 2003), when compared to normal pregnant controls. A recent

432 retrospective study from Iran reported lower plasma selenium concentrations in 40 pre-

433 eclamptic compared to 40 control women (Maleki et al., 2011). Conversely, others have 
434 shown no differences (Rayman et al., 1996) and in one study from the USA, higher sera

435 selenium concentrations have been reported in women with pre-eclampsia (Mahomed et

436 al., 2000). However, a reported lack of sensitivity of the assays used (Rayman et al.,

437 1996), or dependence of the maternal leucocyte selenium content in estimation of

438 selenium status (Mahomed et al., 2000) may confound interpretation of these studies.

440 Selenoprotein GPx activities in both maternal and cord plasma have also been shown to

441 be lower in pre-eclamptic pregnancies. A retrospective study of plasma taken from 25

442 pre-eclamptic and 15 healthy pregnant Turkish women in their $3^{\text {rd }}$ trimester observed

443 significantly lower GPx levels in pre-eclampsia compared to controls (Yildirim et al.,

444 2004). A similar study, also from Turkey, retrospectively collected maternal blood just

445 before delivery, from 30 mild pre-eclamptic (defined as blood pressure $\geq 140 / 90 \mathrm{~mm} \mathrm{Hg}$

446 plus $\geq 300 \mathrm{mg} / 24$ hours proteinuria); 30 severe pre-eclamptic (defined as $\geq 160 / 110 \mathrm{~mm}$

$447 \mathrm{Hg}$ plus $5 \mathrm{~g}$ proteinuria in 24 hours) and 30 normal pregnant women. This study reported

448 lower concentrations of GPx in both pre-eclampsia groups compared to the controls

449 (Bulgan Kilicdag et al., 2005).

451 Several other retrospective studies from the USA (Wang and Walsh, 1996, Walsh and

452 Wang, 1993), Turkey (Atamer et al., 2005) and Australia (Vanderlelie et al., 2005) of

453 placental tissue collected from normal pregnancy and pre-eclampsia report a reduction in

454 GPx activity in pre-eclampsia. Our group recently conducted a retrospective cross-

455 sectional study in the UK of 25 pre-eclamptic women and 27 healthy controls, in which

456 maternal blood samples were collected before delivery, as well as cord blood and 
457 placental tissue immediately after delivery (Mistry et al., 2008). Plasma concentrations

458 of thiobarbituric acid reactive substances (TBARS; a marker for lipid peroxidation) were

459 increased in maternal and cord plasma in the pre-eclamptic group. Moreover, total GPx

460 activity in plasma and in placental tissue were significantly reduced in pre-eclampsia

461 (Mistry et al., 2008). Further prospective, longitudinal studies are required to elucidate a

462 'cause or effect' relationship. If selenium deficiency is confirmed in women suffering

463 from pre-eclampsia, and this continues to be linked with GPx inadequacy, selenium

464 supplementation in pregnancy may be of benefit in prevention or amelioration of pre-

465 eclampsia, a hypothesis which is currently being addressed in a RCT (see below).

467 Some small studies have attempted to assess the influence of selenium supplementation 468 on the incidence of pregnancy related hypertensive disorders, Han et al., conducted a

469 small placebo-controlled RCT in Beijing, China, a population with a high risk of

470 pregnancy-induced hypertension (PIH) and between $26 \%-27 \%$ and selenium deficiency.

47152 women with known risk factors for PIH were randomised to selenium (100 $\mu \mathrm{g} / \mathrm{day})$

472 for 6-8 weeks during late pregnancy, and 48 were randomised to placebo (Han and Zhou,

473 1994). The selenium supplemented group had a reduced incidence of development of PIH

$474(7.7 \% ; 4 / 52)$ compared to the placebo group $(22.7 \% ; 11 / 48)$, and significantly increased

475 maternal and cord blood selenium concentrations. Another very small prospective

476 double-blind, placebo-controlled RCT study in Indonesia, reported lower rates of pre-

477 eclampsia and/or PIH in women who were at increased risk of developing these

478 conditions, after supplementation $(n=29)$ with a range of antioxidants and cofactors

479 including selenium (100 $\mu \mathrm{g})$ (Rumiris et al., 2006). Neither study adequately addressed 
480 the role of supplementation on the incidence of pre-eclampsia. Recently however, Tara $e t$

$481 a l$, investigated selenium supplementation of Iranian women in their first trimester (100

$482 \mu \mathrm{g}$ selenium per day) in a small pilot RCT and concluded that supplementation may be

483 associated with a lower frequency of pre-eclampsia although this didn't quite reach

484 statistical significance (Tara et al., 2010).

485

486 There is no current consensus on the optimal dietary selenium supplement for use in

487 clinical supplementation, since bioavailability and effects on expression of the various

488 selenoproteins depend on the form of selenium product used (Rayman, 2008). A small

489 UK based RCT of selenium supplementation (selenium in pregnancy; SPRINT)

490 conducted by the Universities of Surrey and Oxford is ongoing. Although not powered to

491 demonstrate clinical benefit this study is designed to assess the impact of selenium

492 supplements on pre-eclampsia related biomarkers. Unselected primiparae are recruited

493 between 12 and 16 weeks' gestation. The active treatment is $60 \mu \mathrm{g}$ a day of selenium-

494 enriched yeast, which is intended to normalise blood selenium concentrations. Most

495 selenium in selenium-enriched yeast is in the form of [Se]Met, and supplementation with

496 this yeast has, in the majority of reported studies been shown to increase the activity of

497 the selenoenzymes (Rayman, 2004). If successful, a larger multicentre RCT adequately

498 powered to detect differences in rates of pre-eclampsia will be needed to assess potential

499 clinical benefit.

500

501

502

Preterm labour 
503 Preterm labour (labour $<37$ weeks' gestation) is a major cause of perinatal morbidity and

504 mortality occurring in 6-7\% pregnancies in the developed world and up to $25 \%$ in

505 undeveloped countries (Steer, 2005) and is likely to be of complex origin. Amongst the

506 few studies to have investigated selenium and preterm labour, Dobrzynski et al from

507 Poland reported lower maternal selenium concentrations and reduced maternal and cord

508 plasma GPx activities in 46 women who delivered preterm compared to 42 women

509 delivering at term (Dobrzynski et al., 1998). The low selenium concentrations and GPx

510 activities in the blood of the preterm infants were proposed to contribute to respiratory

511 distress syndrome, retinopathy of prematurity, increased haemolysis or other prematurity

512 related conditions (Dobrzynski et al., 1998). A study from Germany of formula-fed

513 preterm infants (gestational age $<32$ weeks, birthweight $<1500$ g) observed significantly

514 lower mean plasma selenium concentrations compared to healthy term infants who were

515 also formula-fed (Sievers et al., 2001). Another recent report from Iran of 30 preterm

516 (gestational age <34 weeks) and 30 term infants (gestation age $>37$ weeks) also revealed

517 significantly lower serum selenium concentrations in the preterm infants compared to

518 term controls (Iranpour et al., 2009). A study from the USA of 13 preterm and 15 term

519 infants found no differences in maternal plasma selenium concentrations, but also

520 reported that preterm infants had lower selenium concentrations compared to term infants

521 (Mask and Lane, 1993). As might be anticipated, the daily dietary selenium intake was 2-

5223 times higher $(96-134 \mu \mathrm{g})$ than in the subjects reported in the Polish population

523 (Dobrzynski et al., 1998). Evidently, population selenium intake may explain some

524 variation between studies. 
526 Preterm premature (pre-labour) rupture of membranes (PPROM) is a major initiating

527 factor in preterm labour and affects $10-12 \%$ of all pregnancies. PPROM is defined as

528 premature rupture of chorioamniotic membranes before the onset of labour and is

529 associated worldwide with increased rates of neonatal and maternal morbidity and

530 mortality (Parry and Strauss, 1998, ACOG, 2007). Increased generation of ROS as well

531 as antioxidant deficiency may play a important role in the pathophysiology of PPROM,

532 which has been associated with enhancement of collagen degradation and subsequent

533 damage to fetal membrane integrity (Wall et al., 2002, Woods, 2001, Woods et al., 2001).

534 A potential association with selenium has been highlighted through a recent small

535 prospective double blind, placebo-controlled RCT in Iran randomised 166 primigravid

536 pregnant women in the first trimester of pregnancy to receive $100 \mu \mathrm{g} /$ day selenium or

537 placebo until delivery (Tara et al., 2010). The supplemented group demonstrated a

538 significant increase in the mean serum selenium concentration and a reduction in the

539 incidence of PPROM (Tara et al., 2010).

541 Fetal growth restriction

542 Fetal growth restriction or delivery of a small for gestational age infant (SGA) is defined

543 as an individualised birthweight ratio below the $10^{\text {th }}$ percentile, and is associated with

544 increased perinatal mortality and morbidity (Cetin et al., 2004). Some studies of SGA

545 deliveries report a reduced placental selenium concentrations (Klapec et al., 2008),

546 whereas others report higher (Osada et al., 2002, Zadrozna et al., 2009) or unchanged

547 concentrations (Llanos and Ronco, 2009). Strambi et al., demonstrated that in 81 SGA

548 (both term and preterm) retrospective cases from Italy, infant plasma selenium 
549 concentrations were significantly lower compared to adequate-for-gestational age (AGA)

550 infants (Strambi et al., 2004). Again geographical differences may explain the difference

551 between the selenium status in the different studies.

552 A recent investigation by our group in a cohort of adolescent pregnant women from two

553 UK inner cities (Baker et al., 2009) found lower plasma selenium concentrations in

554 mothers who delivered SGA infants compared to mothers who delivered AGA infants

555 (Mistry et al., 2010). A recent series of papers from North Dakota State University

556 suggest some protective effect of high selenium intake in nutrient-restricted pregnant

557 ewes on fetal birthweight and placental development (Lekatz et al., 2010). We are not

558 aware of any ongoing studies investigating maternal and fetal selenium status in relation

559 to fetal growth restriction although these observations would warrant a larger prospective

560 study especially focussing on adolescent pregnant women and those residing in selenium-

561 deficient populations.

562

563 Obstetric cholestasis

564 Obstetric cholestasis (OC) is a serious complication of pregnancy and affects

565 approximately 4,500 women per year in the UK. Affected women develop itching,

566 otherwise-unexplained elevation of plasma liver enzymes and of serum bile acids and

567 occasionally jaundice. OC is associated with an increased risk of premature delivery and

568 fetal distress and is believed to be an important cause of stillbirth (Gurung et al., 2009).

570 Selenium was first linked with OC in 1987 when Kauppila et al demonstrated that serum

571 selenium concentrations were significantly lower in 12 Finnish women with OC when 
572 compared to 12 normal pregnancies during the last trimester and postpartum (Kauppila et

573 al., 1987). Furthermore they also showed GPx activities to be decreased, showing a

574 significant positive correlation with selenium concentration (Kauppila et al., 1987). Thus,

575 it has been hypothesised that inadequate antioxidant protection may lead to hepatocyte

576 oxidative damage and reduce excretion of bile (Akerboom et al., 1984). These initial

577 results have been confirmed and extended in a study of 21 women with OC in Chile, also

578 showing that the decrease in prevalence of OC in Chile during the last decade coincided

579 with an increase in plasma selenium concentrations (Reyes et al., 2000).

580

$581 \quad$ Gestational diabetes mellitus

582 Gestational diabetes mellitus (GDM) is one of the more common diseases in pregnancy,

583 affecting between $2 \%$ and $5 \%$ of pregnant women and is associated with birthweights

584 above the $90^{\text {th }}$ centile, increased levels of primary Caesarean deliveries and neonatal

585 hypoglycaemia (Gilmartin et al., 2008). GDM is defined as a deficient insulin supply

586 relative to the increased demands that are characteristic of pregnancy (Metzger et al.,

587 2007). The causes are not known but are closely related to a constitutional risk of type 2

588 diabetes in later life and strongly associated with obesity. A significant proportion of

589 GDM women develop type 2 diabetes 5-16 years after pregnancy (17-63\% risk) (Kjos et

590 al., 1995, O'Sullivan and Mahan, 1964, Mestman et al., 1972).

591

592 A link between selenium and glucose metabolism has been observed previously in animal

593 studies (Becker et al., 1996, McNeill et al., 1991, Ezaki, 1990) and selenium administered

594 to streptozotocin-diabetic rats showed a restoration of glycemic control and a 
595 modification of the activity of a range of enzymes involved in hepatic glycolysis and

596 glyconeogenesis (Becker et al., 1996). Several studies from China, Kuwait, Turkey and

597 the USA have shown a decrease in maternal plasma selenium concentrations in women

598 with GDM (Tan et al., 2001, Hawkes et al., 2004, Kilinc et al., 2008, Al-Saleh et al.,

599 2004). Bo et al completed a retrospective study investigating selenium intakes through

600 dietary questionnaires in 504 pregnant women (210 with hyperglycemia and 294 healthy

601 controls) as well as measuring serum concentrations in a second cohort (71

602 hyperglycemic and 123 controls) (Bo et al., 2005). A lower dietary intake of selenium

603 was observed in the hyperglycaemic group and in the second cohort, selenium

604 concentrations were significantly lower in the women who had impaired glucose

605 tolerance; both dietary intakes and selenium concentration were negatively associated

606 with gestational hyperglycemia in a multiple regression model (odds ratio 0.97 and 0.92

607 respectively) (Bo et al., 2005).

608

609 An inverse relationship between selenium concentrations and blood glucose

610 concentrations has also been observed (Kilinc et al., 2008, Tan et al., 2001, Hawkes et al.,

611 2004), but was not accompanied by changes in insulin (Hawkes et al 2004) suggesting

612 that selenium may affect glucose metabolism downstream from insulin, or possibly

613 through independent energy regulating pathways such as thyroid hormones (Hawkes et

614 al., 2004). This relationship is unique to pregnancy: diabetes in non-pregnant subjects is

615 associated with higher blood selenium concentrations (Laclaustra et al., 2009).

616

617 Conclusions 
618 There are wide differences in selenium intake across diverse populations, depending on

619 the selenium content of the soil, and hence the selenium content in staple foodstuffs, as

620 well as on variations in individuals' diets. Both deficiency and excess are damaging to

621 health. In turn, varying intakes are associated with differences in selenoprotein and

622 selenoenzyme expression in different tissues. This must be taken into account when

623 comparing data from different countries or populations. Evidently, the balance between

624 intake, tissue concentration and selenoenzyme synthesis is a very delicate one. This

625 review illustrates the potential influence that selenium status has on many disorders

626 relating to both animal and human reproduction and pregnancy. While persuasive

627 evidence already exists to suggest that additional selenium would be beneficial in some of

628 these disorders, results from intervention trials underway or planned have the potential to

629 reinforce or refute the argument for increasing selenium intake.

630

631

632

633

634

635

636

637

638

639

640 


\section{References}

642

643

644

645

646

647

648

649

650

651

652

653

654

655

656

657

658

659

660

661

662

663

664

665

666

667

668

669

670

671

672

673

674

675

676

677

678

679

680

681

682

683

684

Abedelahi, A, Salehnia, M, Allameh, AA \& Davoodi, D (2010) Sodium selenite improves the in vitro follicular development by reducing the reactive oxygen species level and increasing the total antioxidant capacity and glutathione peroxide activity. Hum Reprod.

ACOG (2007) Premature rupture of membranes. ACOG Practice Bulletin. No. 80.

Akerboom, TP, Bilzer, M \& Sies, H (1984) Relation between glutathione redox changes and biliary excretion of taurocholate in perfused rat liver. J Biol Chem 259, 58385843.

Al-Kunani, AS, Knight, R, Haswell, SJ, Thompson, JW \& Lindow, SW (2001) The selenium status of women with a history of recurrent miscarriage. BJOG 108, 1094-1097.

Al-Saleh, E, Nandakumaran, M, Al-Shammari, M \& Al-Harouny, A (2004) Maternalfetal status of copper, iron, molybdenum, selenium and zinc in patients with gestational diabetes. J Matern Fetal Neonatal Med 16, 15-21.

Alanne, M, Kristiansson, K, Auro, K, Silander, K, Kuulasmaa, K, Peltonen, L, et al. (2007) Variation in the selenoprotein $S$ gene locus is associated with coronary heart disease and ischemic stroke in two independent Finnish cohorts. Hum Genet 122, 355-365.

Allan, CB, Lacourciere, GM \& Stadtman, TC (1999) Responsiveness of selenoproteins to dietary selenium. Annu Rev Nutr 19, 1-16.

Arner, ES (2009) Focus on mammalian thioredoxin reductases--important selenoproteins with versatile functions. Biochim Biophys Acta 1790, 495-526.

Atamer, Y, Kocyigit, Y, Yokus, B, Atamer, A \& Erden, AC (2005) Lipid peroxidation, antioxidant defense, status of trace metals and leptin levels in preeclampsia. Eur $J$ Obstet Gynecol Reprod Biol 119, 60-66.

Baker, PN, Wheeler, SJ, Sanders, TA, Thomas, JE, Hutchinson, CJ, Clarke, K, et al. (2009) A prospective study of micronutrient status in adolescent pregnancy. Am J Clin Nutr 89, 1114-1124.

Barrington, JW, Lindsay, P, James, D, Smith, S \& Roberts, A (1996) Selenium deficiency and miscarriage: a possible link? Br J Obstet Gynaecol 103, 130-132.

Barrington, JW, Taylor, M, Smith, S \& Bowen-Simpkins, P (1997) Selenium and recurrent miscarriage. J Obstet Gynaecol 17, 199-200.

Bauer, F (1997) Selenium and Soils in the Western United States. In: Electronic Green Journal. eScholarship Repository; UCLA Library, University of California, Los Angeles.

Beck, MA, Levander, OA \& Handy, J (2003) Selenium deficiency and viral infection. $J$ Nutr 133, 1463S-1467S.

Becker, DJ, Reul, B, Ozcelikay, AT, Buchet, JP, Henquin, JC \& Brichard, SM (1996) Oral selenate improves glucose homeostasis and partly reverses abnormal expression of liver glycolytic and gluconeogenic enzymes in diabetic rats. Diabetologia 39, 3-11.

Beckett, GJ \& Arthur, JR (2005) Selenium and endocrine systems. J Endocrinol 184, 455-465. 
685

686

687

688

689

690

691

692

693

694

695

696

697

698

699

700

701

702

703

704

705

706

707

708

709

710

711

712

713

714

715

716

717

718

719

720

721

722

723

724

725

726

727

728

729

730
Behne, D, Weiler, H \& Kyriakopoulos, A (1996) Effects of selenium deficiency on testicular morphology and function in rats. J Reprod Fertil 106, 291-297.

Bleau, G, Lemarbre, J, Faucher, G, Roberts, KD \& Chapdelaine, A (1984) Semen selenium and human fertility. Fertil Steril 42, 890-894.

Bo, S, Lezo, A, Menato, G, Gallo, ML, Bardelli, C, Signorile, A, et al. (2005) Gestational hyperglycemia, zinc, selenium, and antioxidant vitamins. Nutrition 21, 186-191.

Bradley, E \& Hamilton-Fairley, D (1998) Managing miscarriage in early pregnancy assessment units. Hosp Med 59, 451-456.

Brigelius-Flohe, R (2008) Selenium compounds and selenoproteins in cancer. Chem Biodivers 5, 389-395.

Brigelius-Flohe, R, Banning, A \& Schnurr, K (2003) Selenium-dependent enzymes in endothelial cell function. Antioxid Redox Signal 5, 205-215.

Broughton Pipkin, F (2001) Risk factors for preeclampsia. N Engl J Med 344, 925-926.

Bulgan Kilicdag, E, Ay, G, Celik, A, Ustundag, B, Ozercan, I \& Simsek, M (2005) Oxidant-antioxidant system changes relative to placental-umbilical pathology in patients with preeclampsia. Hypertens Pregnancy 24, 147-157.

Burk, RF, Hill, KE \& Motley, AK (2003) Selenoprotein metabolism and function: evidence for more than one function for selenoprotein P. J Nutr 133, 1517S$1520 \mathrm{~S}$.

Burk, RF \& Levander, OA (2006) Selenium. In: Modern nutrition in health and disease. eds Shils, ME, Shike, M, Ross, AC, Caballero, B \& Cousins, RJ) Tenth edn. Lippincott Williams \& Wilkins, Philadelphia.

Burton, GJ, Yung, HW, Cindrova-Davies, T \& Charnock-Jones, DS (2009) Placental endoplasmic reticulum stress and oxidative stress in the pathophysiology of unexplained intrauterine growth restriction and early onset preeclampsia. Placenta 30 Suppl A, S43-48.

Cetin, I, Foidart, JM, Miozzo, M, Raun, T, Jansson, T, Tsatsaris, V, et al. (2004) Fetal growth restriction: a workshop report. Placenta 25, 753-757.

Chappell, S \& Morgan, L (2006) Searching for genetic clues to the causes of preeclampsia. Clin Sci (Lond) 110, 443-458.

Chun, OK, Floegel, A, Chung, SJ, Chung, CE, Song, WO \& Koo, SI (2010) Estimation of antioxidant intakes from diet and supplements in U.S. adults. $J$ Nutr 140, 317 324.

Cincotta, RB \& Brennecke, SP (1998) Family history of pre-eclampsia as a predictor for pre-eclampsia in primigravidas. Int J Gynaecol Obstet 60, 23-27.

Combs, GF, Jr. (2001) Selenium in global food systems. Br J Nutr 85, 517-547.

Dawson, EB, Evans, DR \& Nosovitch, J (1999) Third-trimester amniotic fluid metal levels associated with preeclampsia. Arch Environ Health 54, 412-415.

Department of Health (1991) Dietary reference values for food energy and nutrients for the United Kingdom. Report on Social Subjects no. 41. London.

Department of Health (1998) Statement from the Committe on Medical Aspects of Food and Nutrition Policy on Selenium. The Stationery Office, London.

Department of Health (2009) National Diet and Nutrition Survey. eds Bates, B, Lennox, A \& Swan, G). Deapartment of Health \& Food Standards Agency.

Diplock, AT (1993) Indexes of selenium status in human populations. Am J Clin Nutr 57, $256 \mathrm{~S}-258 \mathrm{~S}$. 
Dobrzynski, W, Trafikowska, U, Trafikowska, A, Pilecki, A, Szymanski, W \& Zachara, BA (1998) Decreased selenium concentration in maternal and cord blood in preterm compared with term delivery. Analyst 123, 93-97.

Drasch, G, Mail der, S, Schlosser, C \& Roider, G (2000) Content of non-mercuryassociated selenium in human tissues. Biol Trace Elem Res 77, 219-230.

Duthie, GG, Arthur, JR, Beattie, JA, Brown, KM, Morrice, PC, Robertson, JD, et al. (1993) Cigarette smoking, antioxidants, lipid peroxidation, and coronary heart disease. Ann N Y Acad Sci 686, 120-129.

European Commission Health and Consumer Protection Directorate (2000) Opinion of the Scientific Committee on Food on the tolerable upper intake level of selenium. SCF/CS/NUT/UPPLEV/25 Final

Ezaki, O (1990) The insulin-like effects of selenate in rat adipocytes. J Biol Chem 265, 1124-1128.

Fairweather-Tait, SJ, Collings, R \& Hurst, R (2010) Selenium bioavailability: current knowledge and future research requirements. Am J Clin Nutr.

Flohe, L (2007) Selenium in mammalian spermiogenesis. Biol Chem 388, 987-995.

Flohe, L, Andreesen, JR, Brigelius-Flohe, R, Maiorino, M \& Ursini, F (2000) Selenium, the element of the moon, in life on earth. IUBMB Life 49, 411-420.

Gathwala, G, Yadav, OP, Singh, I \& Sangwan, K (2000) Maternal and cord plasma selenium levels in full-term neonates. Indian J Pediatr 67, 729-731.

Gilmartin, AB, Ural, SH \& Repke, JT (2008) Gestational diabetes mellitus. Rev Obstet Gynecol 1, 129-134.

Gissel-Nielsen, G (1998) Effects of selenium supplementation of food crops In: Environmental Chemistry of Selenium. eds Frankenberger Jr, WT \& Engberg, RA). Marcel Dekker, New York.

Goldhaber, SB (2003) Trace element risk assessment: essentiality vs. toxicity. Regul Toxicol Pharmacol 38, 232-242.

Gurung, V, Williamson, C, Chappell, L, Chambers, J, Briley, A, Broughton Pipkin, F, et al. (2009) Pilot study for a trial of ursodeoxycholic acid and/or early delivery for obstetric cholestasis. BMC Pregnancy Childbirth 9, 19.

Han, L \& Zhou, SM (1994) Selenium supplement in the prevention of pregnancy induced hypertension. Chin Med J (Engl) 107, 870-871.

Hawkes, WC, Alkan, Z, Lang, K \& King, JC (2004) Plasma selenium decrease during pregnancy is associated with glucose intolerance. Biol Trace Elem Res 100, 19-29.

Hesketh, J (2008) Nutrigenomics and selenium: gene expression patterns, physiological targets, and genetics. Annu Rev Nutr 28, 157-177.

Hidiroglou, M (1979) Trace element deficiencies and fertility in ruminants: a review. $J$ Dairy Sci 62, 1195-1206.

Hill, KE, Zhou, J, McMahan, WJ, Motley, AK, Atkins, JF, Gesteland, RF, et al. (2003) Deletion of selenoprotein $\mathrm{P}$ alters distribution of selenium in the mouse. $\mathrm{J} \mathrm{Biol}$ Chem 278, 13640-13646.

Hirschfeld, AF, Jiang, R, Robinson, WP, McFadden, DE \& Turvey, SE (2007) Toll-like receptor 4 polymorphisms and idiopathic chromosomally normal miscarriage. Hum Reprod 22, 440-443. 
Howard, JM, Davies, S \& Hunnisett, A (1994) Red cell magnesium and glutathione peroxidase in infertile women--effects of oral supplementation with magnesium and selenium. Magnes Res 7, 49-57.

Hubel, CA (1999) Oxidative stress in the pathogenesis of preeclampsia. Proc Soc Exp Biol Med 222, 222-235.

Hung, TH \& Burton, GJ (2006) Hypoxia and reoxygenation: a possible mechanism for placental oxidative stress in preeclampsia. Taiwan J Obstet Gynecol 45, 189-200.

Hurst, R, Armah, CN, Dainty, JR, Hart, DJ, Teucher, B, Goldson, AJ, et al. (2010) Establishing optimal selenium status: results of a randomized, double-blind, placebo-controlled trial. Am J Clin Nutr 91, 923-931.

Institute of Medicine (2000) Food and Nutrition Board. In: Dietary Reference Intakes for Vitamin C, Vitamin E, Selenium, and Carotenoids. National Academy Press Washington DC.

Ip, C (1998) Lessons from basic research in selenium and cancer prevention. J Nutr 128, 1845-1854.

Iranpour, R, Zandian, A, Mohammadizadeh, M, Mohammadzadeh, A, Balali-Mood, M \& Hajiheydari, M (2009) Comparison of maternal and umbilical cord blood selenium levels in term and preterm infants. Zhongguo Dang Dai Er Ke Za Zhi 11, 513-516.

Irvine, DS (1996) Glutathione as a treatment for male infertility. Rev Reprod 1, 6-12.

Jackson, MJ, Dillon, SA, Broome, CS, McArdle, A, Hart, CA \& McArdle, F (2004) Are there functional consequences of a reduction in selenium intake in UK subjects? Proc Nutr Soc 63, 513-517.

Jauniaux, E, Poston, L \& Burton, GJ (2006) Placental-related diseases of pregnancy: Involvement of oxidative stress and implications in human evolution. Hum Reprod Update 12, 747-755.

Judd, PA, Long, A, Butcher, M, Caygill, CP \& Diplock, AT (1997) Vegetarians and vegans may be most at risk from low selenium intakes. BMJ 314, 1834a-.

Kauppila, A, Korpela, H, Makila, UM \& Yrjanheikki, E (1987) Low serum selenium concentration and glutathione peroxidase activity in intrahepatic cholestasis of pregnancy. Br Med J (Clin Res Ed) 294, 150-152.

Keskes-Ammar, L, Feki-Chakroun, N, Rebai, T, Sahnoun, Z, Ghozzi, H, Hammami, S, et al. (2003) Sperm oxidative stress and the effect of an oral vitamin $E$ and selenium supplement on semen quality in infertile men. Arch Androl 49, 83-94.

Kilinc, M, Guven, MA, Ezer, M, Ertas, IE \& Coskun, A (2008) Evaluation of serum selenium levels in Turkish women with gestational diabetes mellitus, glucose intolerants, and normal controls. Biol Trace Elem Res 123, 35-40.

Kjos, SL, Peters, RK, Xiang, A, Henry, OA, Montoro, M \& Buchanan, TA (1995) Predicting future diabetes in Latino women with gestational diabetes. Utility of early postpartum glucose tolerance testing. Diabetes $\mathbf{4 4}, 586-591$.

Klapec, T, Cavar, S, Kasac, Z, Rucevic, S \& Popinjac, A (2008) Selenium in placenta predicts birth weight in normal but not intrauterine growth restriction pregnancy. $J$ Trace Elem Med Biol 22, 54-58.

Knapen, MF, Zusterzeel, PL, Peters, WH \& Steegers, EA (1999) Glutathione and glutathione-related enzymes in reproduction. A review. Eur J Obstet Gynecol Reprod Biol 82, 171-184. 
Kocak, I, Aksoy, E \& Ustun, C (1999) Recurrent spontaneous abortion and selenium deficiency. Int J Gynaecol Obstet 65, 79-80.

Kohrle, J, Jakob, F, Contempre, B \& Dumont, JE (2005) Selenium, the thyroid, and the endocrine system. Endocr Rev 26, 944-984.

Koller, LD \& Exon, JH (1986) The two faces of selenium-deficiency and toxicity--are similar in animals and man. Can J Vet Res 50, 297-306.

Kryukov, GV, Castellano, S, Novoselov, SV, Lobanov, AV, Zehtab, O, Guigo, R, et al. (2003) Characterization of mammalian selenoproteomes. Science 300, 1439-1443.

Kumar, KS, Kumar, A, Prakash, S, Swamy, K, Jagadeesan, V \& Jyothy, A (2002) Role of red cell selenium in recurrent pregnancy loss. J Obstet Gynaecol 22, 181-183.

Kundu, N, Parke, P, Palmer, IS, Olson, O \& Petersen, LP (1985) Distribution of serum selenium, copper, and zinc in normal human pregnancy. Arch Environ Health 40, 268-273.

Laclaustra, M, Navas-Acien, A, Stranges, S, Ordovas, JM \& Guallar, E (2009) Serum selenium concentrations and diabetes in U.S. adults: National Health and Nutrition Examination Survey (NHANES) 2003-2004. Environ Health Perspect 117, 1409-1413.

Lekatz, LA, Caton, JS, Taylor, JB, Reynolds, LP, Redmer, DA \& Vonnahme, KA (2010) Maternal selenium supplementation and timing of nutrient restriction in pregnant sheep: effects on maternal endocrine status and placental characteristics. J Anim Sci 88, 955-971.

Levander, OA (1987) Selenium. In: Trace Elements in Human and Animal Nutrition. (ed Orlando, FL). Academic Press Inc, London.

Levander, OA \& Beck, MA (1997) Interacting nutritional and infectious etiologies of Keshan disease. Insights from coxsackie virus B-induced myocarditis in mice deficient in selenium or vitamin E. Biol Trace Elem Res 56, 5-21.

Levander, OA \& Burk, RF (1994) Selenium. In: Modern Nutrition in Health and Disease. eds Shils, ME, Olson, JA \& Shike, M) 8th edn. Lea and Febiger, Philadelphia.

Lie, RT, Rasmussen, S, Brunborg, H, Gjessing, HK, Lie-Nielsen, E \& Irgens, LM (1998) Fetal and maternal contributions to risk of pre-eclampsia: population based study. BMJ 316, 1343-1347.

Lippman, SM, Klein, EA, Goodman, PJ, Lucia, MS, Thompson, IM, Ford, LG, et al. (2009) Effect of selenium and vitamin $E$ on risk of prostate cancer and other cancers: the Selenium and Vitamin E Cancer Prevention Trial (SELECT). JAMA 301, 39-51.

Llanos, MN \& Ronco, AM (2009) Fetal growth restriction is related to placental levels of cadmium, lead and arsenic but not with antioxidant activities. Reprod Toxicol 27, 88-92.

Longnecker, MP, Taylor, PR, Levander, OA, Howe, M, Veillon, C, McAdam, PA, et al. (1991) Selenium in diet, blood, and toenails in relation to human health in a seleniferous area. Am J Clin Nutr 53, 1288-1294.

Lu, J \& Holmgren, A (2009) Selenoproteins. J Biol Chem 284, 723-727.

Lyons, G, Stangoulis, J \& Graham, R (2003) Nutriprevention of Disease with HighSelenium Wheat. Journal of Australasian College of Nutritional Medicine 22, 3-9. 
Mahomed, K, Williams, MA, Woelk, GB, Mudzamiri, S, Madzime, S, King, IB, et al. (2000) Leukocyte selenium, zinc, and copper concentrations in preeclamptic and normotensive pregnant women. Biol Trace Elem Res 75, 107-118.

Maleki, A, Fard, MK, Zadeh, DH, Mamegani, MA, Abasaizadeh, S \& Mazloomzadeh, S (2011) The Relationship between Plasma Level of Se and Preeclampsia. Hypertens Pregnancy.

Mask, G \& Lane, HW (1993) Selected measures of selenium status in full-term and preterm neonates, their mothers and non-pregnant women. Nutrition Research 13, 901-911.

McKenzie, RC, Rafferty, TS \& Beckett, GJ (1998) Selenium: an essential element for immune function. Immunol Today 19, 342-345.

McNeill, JH, Delgatty, HL \& Battell, ML (1991) Insulinlike effects of sodium selenate in streptozocin-induced diabetic rats. Diabetes 40, 1675-1678.

Meplan, C, Crosley, LK, Nicol, F, Horgan, GW, Mathers, JC, Arthur, JR, et al. (2008) Functional effects of a common single-nucleotide polymorphism (GPX4c718t) in the glutathione peroxidase 4 gene: interaction with sex. Am J Clin Nutr 87, 10191027.

Mestman, JH, Anderson, GV \& Guadalupe, V (1972) Follow-up study of 360 subjects with abnormal carbohydrate metabolism during pregnancy. Obstet Gynecol 39, 421-425.

Metzger, BE, Buchanan, TA, Coustan, DR, de Leiva, A, Dunger, DB, Hadden, DR, et al. (2007) Summary and recommendations of the Fifth International WorkshopConference on Gestational Diabetes Mellitus. Diabetes Care 30 Suppl 2, S251260.

Mihailovic, M, Cvetkovic, M, Ljubic, A, Kosanovic, M, Nedeljkovic, S, Jovanovic, I, et al. (2000) Selenium and malondialdehyde content and glutathione peroxidase activity in maternal and umbilical cord blood and amniotic fluid. Biol Trace Elem Res 73, 47-54.

Ministry Of Agriculture Fisheries and Food (1997) Dietary Intake of Selenium. (ed Joint Food Safety and Standards Group). H.M. Stationery Office, London.

Mistry, HD, Kurlak, LO, Young, SY, Briley, AL, Broughton Pipkin, F \& Poston, L (2010) Reduced plasma selenium in adolescent mothers with small for gestational age infants; impact of smoking and ethnicity. In: Society for Gynecologic Investigation. Reproductive Sciences, Orlando.

Mistry, HD, Wilson, V, Ramsay, MM, Symonds, ME \& Broughton Pipkin, F (2008) Reduced selenium concentrations and glutathione peroxidase activity in preeclamptic pregnancies. Hypertension 52, 881-888.

Moore, MA, Wander, RC, Xia, YM, Du, SH, Butler, JA \& Whanger, PD (2000) Selenium supplementation of Chinese women with habitually low selenium intake increases plasma selenium, plasma glutathione peroxidase activity, and milk selenium, but not milk glutathione peroxidase activity. J Nutr Biochem 11, 341347.

Moreno-Reyes, R, Mathieu, F, Boelaert, M, Begaux, F, Suetens, C, Rivera, MT, et al. (2003) Selenium and iodine supplementation of rural Tibetan children affected by Kashin-Beck osteoarthropathy. Am J Clin Nutr 78, 137-144. 
910

911

912

913

914

915

916

917

918

919

920

921

922

923

924

925

926

927

928

929

930

931

932

933

934

935

936

937

938

939

940

941

942

943

944

945

946

947

948

949

950

951

952

953

954

Moses, EK, Johnson, MP, Tommerdal, L, Forsmo, S, Curran, JE, Abraham, LJ, et al. (2008) Genetic association of preeclampsia to the inflammatory response gene SEPS1. Am J Obstet Gynecol 198, 336 e331-335.

Mostert, V, Hill, KE \& Burk, RF (2003) Loss of activity of the selenoenzyme thioredoxin reductase causes induction of hepatic heme oxygenase-1. FEBS Lett 541, 85-88.

MTT Agrifood Research Finland (2005) Fertilization has guaranteed the selenium intake of Finns.

Nandakumaran, M, Dashti, HM, Al-Saleh, E \& Al-Zaid, NS (2003) Transport kinetics of zinc, copper, selenium, and iron in perfused human placental lobule in vitro. $\mathrm{Mol}$ Cell Biochem 252, 91-96.

Nandakumaran, M, Dashti, HM \& Al-Zaid, NS (2002) Maternal-fetal transport kinetics of copper, selenium, magnesium and iron in perfused human placental lobule: in vitro study. Mol Cell Biochem 231, 9-14.

Northrop-Clewes, CA \& Thurnham, DI (2007) Monitoring micronutrients in cigarette smokers. Clin Chim Acta 377, 14-38.

O'Sullivan, JB \& Mahan, CM (1964) Criteria for the Oral Glucose Tolerance Test in Pregnancy. Diabetes 13, 278-285.

Oldfield, JE (1987) The two faces of selenium. J Nutr 117, 2002-2008.

Oldfield, JE (1997) Observations on the efficacy of various forms of selenium for livestock: a review. Biomed Environ Sci 10, 280-291.

Oldfield, JE (2002) A brief history of selenium research: from alkali disease to prostate cancer (from poison to prevention). American Society of Animal Science.

Osada, H, Watanabe, Y, Nishimura, Y, Yukawa, M, Seki, K \& Sekiya, S (2002) Profile of trace element concentrations in the feto-placental unit in relation to fetal growth. Acta Obstet Gynecol Scand 81, 931-937.

Oster, O \& Prellwitz, W (1990) The renal excretion of selenium. Biol Trace Elem Res 24, 119-146.

Ozkaya, MO, Naziroglu, M, Barak, C \& Berkkanoglu, M (2010) Effects of Multivitamin/Mineral Supplementation on Trace Element Levels in Serum and Follicular Fluid of Women Undergoing in Vitro Fertilization (IVF). Biol Trace Elem Res.

Parry, S \& Strauss, JF, 3rd (1998) Premature rupture of the fetal membranes. N Engl J Med 338, 663-670.

Paszkowski, T, Traub, AI, Robinson, SY \& McMaster, D (1995) Selenium dependent glutathione peroxidase activity in human follicular fluid. Clin Chim Acta 236, 173-180.

Patrick, L (2004) Selenium biochemistry and cancer: a review of the literature. Altern Med Rev 9, 239-258.

Poston, L (2004) The Role of Oxidative Stress. In: Pre-eclampsia. eds Critchley, H, MacLean, A, Poston, L \& Walker, J). RCOG Press, London.

Poston, L (2006) Endothelial dysfunction in pre-eclampsia. Pharmacol Rep 58 Suppl, 6974.

Rayman, MP (2000) The importance of selenium to human health. Lancet 356, 233-241.

Rayman, MP (2002) The argument for increasing selenium intake. Proc Nutr Soc 61, 203-215. 
955

956

957

958

959

960

961

962

963

964

965

966

967

968

969

970

971

972

973

974

975

976

977

978

979

980

981

982

983

984

985

986

987

988

989

990

991

992

993

994

995

996

997

998

999

1000
Rayman, MP (2004) The use of high-selenium yeast to raise selenium status: how does it measure up? Br J Nutr 92, 557-573.

Rayman, MP (2008) Food-chain selenium and human health: emphasis on intake. $\mathrm{Br} J$ Nutr 100, 254-268.

Rayman, MP, Abou-Shakra, FR, Ward, NI \& Redman, CW (1996) Comparison of selenium levels in pre-eclamptic and normal pregnancies. Biol Trace Elem Res 55, 9-20.

Rayman, MP, Bode, P \& Redman, CW (2003) Low selenium status is associated with the occurrence of the pregnancy disease preeclampsia in women from the United Kingdom. Am J Obstet Gynecol 189, 1343-1349.

Redman, CW \& Sargent, IL (2003) Pre-eclampsia, the placenta and the maternal systemic inflammatory response--a review. Placenta 24 Suppl A, S21-27.

Reilly, C (2006) Selenium in food and health. Springer, New York.

Reyes, H, Baez, ME, Gonzalez, MC, Hernandez, I, Palma, J, Ribalta, J, et al. (2000) Selenium, zinc and copper plasma levels in intrahepatic cholestasis of pregnancy, in normal pregnancies and in healthy individuals, in Chile. J Hepatol 32, 542-549.

Roberts, JM \& Lain, KY (2002) Recent Insights into the pathogenesis of pre-eclampsia. Placenta 23, 359-372.

Robinson, MF, McKenzie, JM, Thomson, CD \& van Rij, AL (1973) Metabolic balance of zinc, copper, cadmium, iron, molybdenum and selenium in young New Zealand women. Br J Nutr 30, 195-205.

Roig, I, Garcia, R, Robles, P, Cortvrindt, R, Egozcue, J, Smitz, J, et al. (2006) Human fetal ovarian culture permits meiotic progression and chromosome pairing process. Hum Reprod 21, 1359-1367.

Ross, C, Morriss, A, Khairy, M, Khalaf, Y, Braude, P, Coomarasamy, A, et al. (2010) A systematic review of the effect of oral antioxidants on male infertility. Reprod Biomed Online.

Rotruck, JT, Pope, AL, Ganther, HE, Swanson, AB, Hafeman, DG \& Hoekstra, WG (1973) Selenium: biochemical role as a component of glutathione peroxidase. Science 179, 588-590.

Roy, SK \& Treacy, BJ (1993) Isolation and long-term culture of human preantral follicles. Fertil Steril 59, 783-790.

Ruder, EH, Hartman, TJ \& Goldman, MB (2009) Impact of oxidative stress on female fertility. Curr Opin Obstet Gynecol 21, 219-222.

Rumiris, D, Purwosunu, Y, Wibowo, N, Farina, A \& Sekizawa, A (2006) Lower rate of preeclampsia after antioxidant supplementation in pregnant women with low antioxidant status. Hypertens Pregnancy 25, 241-253.

Safarinejad, MR \& Safarinejad, S (2009) Efficacy of selenium and/or N-acetyl-cysteine for improving semen parameters in infertile men: a double-blind, placebo controlled, randomized study. J Urol 181, 741-751.

Schwarz, K \& Foltz, CM (1957) Selenium as an integral part of factor 3 against dietary necrotic liver degeneration. J. Am. Chem. Soc. 79, 3292-3293.

Scott, R, MacPherson, A, Yates, RW, Hussain, B \& Dixon, J (1998) The effect of oral selenium supplementation on human sperm motility. Br J Urol 82, 76-80.

Shennan, DB (1987) A study of selenate efflux from human placental microvillus membrane vesicles. Biosci Rep 7, 675-680. 
1001

1002

1003

1004

1005

1006

1007

1008

1009

1010

1011

1012

1013

1014

1015

1016

1017

1018

1019

1020

1021

1022

1023

1024

1025

1026

1027

1028

1029

1030

1031

1032

1033

1034

1035

1036

1037

1038

1039

1040

1041

1042

1043

1044

1045

Shennan, DB (1988) Selenium (selenate) transport by human placental brush border membrane vesicles. Br J Nutr 59, 13-19.

Sibai, B, Dekker, G \& Kupferminc, M (2005) Pre-eclampsia. Lancet 365, 785-799.

Sievers, E, Arpe, T, Schleyerbach, U, Garbe-Schonberg, D \& Schaub, J (2001) Plasma selenium in preterm and term infants during the first 12 months of life. $J$ Trace Elem Med Biol 14, 218-222.

Smith, AM \& Picciano, MF (1986) Evidence for increased selenium requirement for the rat during pregnancy and lactation. J Nutr 116, 1068-1079.

Steegers, EA, von Dadelszen, P, Duvekot, JJ \& Pijnenborg, R (2010) Pre-eclampsia. Lancet.

Steer, P (2005) The epidemiology of preterm labor--a global perspective. J Perinat Med 33, 273-276.

Strambi, M, Longini, M, Vezzosi, P, Berni, S \& Buoni, S (2004) Selenium status, birth weight, and breast-feeding: pattern in the first month. Biol Trace Elem Res 99, 7181.

Stuart, LD \& Oehme, FW (1982) Environmental factors in bovine and porcine abortion. Vet Hum Toxicol 24, 435-441.

Sunde, RA (1990) Molecular biology of selenoproteins. Annu Rev Nutr 10, 451-474.

Surai, PF (2006) Selenium in Nutrition and Health. Nottingham University Press UK, Nottingham.

Tan, M, Sheng, L, Qian, Y, Ge, Y, Wang, Y, Zhang, H, et al. (2001) Changes of serum selenium in pregnant women with gestational diabetes mellitus. Biol Trace Elem Res 83, 231-237.

Tara, F, Rayman, MP, Boskabadi, H, Ghayour-Mobarhan, M, Sahebkar, A, Yazarlu, O, et al. (2010) Selenium supplementation and premature (pre-labour) rupture of membranes: a randomised double-blind placebo-controlled trial. $J$ Obstet Gynaecol 30, 30-34.

Thompson, JN, Erdody, P \& Smith, DC (1975) Selenium content of food consumed by Canadians. J Nutr 105, 274-277.

Thomson, CD (2004) Assessment of requirements for selenium and adequacy of selenium status: a review. Eur J Clin Nutr 58, 391-402.

Thomson, CD \& Robinson, MF (1986) Urinary and fecal excretions and absorption of a large supplement of selenium: superiority of selenate over selenite. Am J Clin Nutr 44, 659-663.

Thomson, CD, Robinson, MF, Butler, JA \& Whanger, PD (1993) Long-term supplementation with selenate and selenomethionine: selenium and glutathione peroxidase (EC 1.11.1.9) in blood components of New Zealand women. Br J Nutr 69, 577-588.

Twomey, T, Crinion, RAP \& Glazier, DB (1977) Selenium toxicity in cattle in Co. Meath. Irish Veterinary Journal 31, 41-46.

Ursini, F, Heim, S, Kiess, M, Maiorino, M, Roveri, A, Wissing, J, et al. (1999) Dual function of the selenoprotein PHGPx during sperm maturation. Science 285, 1393-1396.

Van Dorst, SH \& Peterson, PJ (1984) Selenium speciation in the soil solution and its relevance to plant uptake. J. Sci. Food Agric. 35, 601-605. 
1046

1047

1048

1049

1050

1051

1052

1053

1054

1055

1056

1057

1058

1059

1060

1061

1062

1063

1064

1065

1066

1067

1068

1069

1070

1071

1072

1073

1074

1075

1076

1077

1078

1079

1080

1081

1082

1083

1084

1085

1086

1087

1088

1089
Van Vleet, JF (1980) Current knowledge of selenium-vitamin E deficiency in domestic animals. J Am Vet Med Assoc 176, 321-325.

Vanderlelie, J, Venardos, K, Clifton, VL, Gude, NM, Clarke, FM \& Perkins, AV (2005) Increased biological oxidation and reduced anti-oxidant enzyme activity in preeclamptic placentae. Placenta 26, 53-58.

Voetsch, B, Jin, RC, Bierl, C, Benke, KS, Kenet, G, Simioni, P, et al. (2007a) Promoter polymorphisms in the plasma glutathione peroxidase $(\mathrm{GPx}-3)$ gene: a novel risk factor for arterial ischemic stroke among young adults and children. Stroke 38, 4149.

Voetsch, B, Jin, RC, Bierl, C, Deus-Silva, L, Camargo, EC, Annichino-Bizacchi, JM, et al. (2007b) Role of Promoter Polymorphisms in the Plasma Glutathione Peroxidase (GPx-3) Gene as a Risk Factor for Cerebral Venous Thrombosis. Stroke.

Wall, PD, Pressman, EK \& Woods, JR, Jr. (2002) Preterm premature rupture of the membranes and antioxidants: the free radical connection. J Perinat Med 30, 447457.

Walsh, SW \& Wang, Y (1993) Deficient glutathione peroxidase activity in preeclampsia is associated with increased placental production of thromboxane and lipid peroxides. Am J Obstet Gynecol 169, 1456-1461.

Wang, Y \& Walsh, SW (1996) Antioxidant activities and mRNA expression of superoxide dismutase, catalase, and glutathione peroxidase in normal and preeclamptic placentas. J Soc Gynecol Investig 3, 179-184.

Welsh, SO, Holden, JM, Wolf, WR \& Levander, OA (1981) Selenium in self-selected diets of Maryland residents. J Am Diet Assoc 79, 277-285.

WHO/FAO/IAEA (1996) Trace Elements in Human Nutrition and Health. World Health Organisation, Geneva.

Woods, JR, Jr. (2001) Reactive oxygen species and preterm premature rupture of membranes-a review. Placenta 22 Suppl A, S38-44.

Woods, JR, Jr., Plessinger, MA \& Miller, RK (2001) Vitamins C and E: missing links in preventing preterm premature rupture of membranes? Am J Obstet Gynecol 185, $5-10$.

Wu, SH, Oldfield, JE, Whanger, PD \& Weswig, PH (1973) Effect of selenium, vitamin E, and antioxidants on testicular function in rats. Biol Reprod 8, 625-629.

Yang, G \& Zhou, R (1994) Further observations on the human maximum safe dietary selenium intake in a seleniferous area of China. J Trace Elem Electrolytes Health Dis 8, 159-165.

Yang, G, Zhou, R, Yin, S, Gu, L, Yan, B, Liu, Y, et al. (1989) Studies of safe maximal daily dietary selenium intake in a seleniferous area in China. I. Selenium intake and tissue selenium levels of the inhabitants. J Trace Elem Electrolytes Health Dis 3, 77-87.

Yang, GQ, GE, K, Chen, J \& Chen, X (1988) Selenium-related endemic diseases and the daily selenium requirement of humans. World Rev. Nutr. Diet 55, 98-152.

Yang, GQ, Wang, SZ, Zhou, RH \& Sun, SZ (1983) Endemic selenium intoxication of humans in China. Am J Clin Nutr 37, 872-881. 
1090

1091

1092

1093

1094

1095

1096

1097

1098

1099

1100

1101

1102

1103

1104

1105

1106

1107

1108

1109
Ye, Y, Shibata, Y, Yun, C, Ron, D \& Rapoport, TA (2004) A membrane protein complex mediates retro-translocation from the ER lumen into the cytosol. Nature 429, 841847.

Yildirim, A, Altinkaynak, K, Aksoy, H, Sahin, YN \& Akcay, F (2004) Plasma xanthine oxidase, superoxide dismutase and glutathione peroxidase activities and uric acid levels in severe and mild pre-eclampsia. Cell Biochem Funct 22, 213-217.

Zachara, BA, Dobrzynski, W, Trafikowska, U \& Szymanski, W (2001) Blood selenium and glutathione peroxidases in miscarriage. BJOG 108, 244-247.

Zachara, BA, Mikolajczak, J \& Trafikowska, U (1993a) Effect of various dietary selenium (Se) intakes on tissue Se levels and glutathione peroxidase activities in lambs. Zentralbl Veterinarmed A 40, 310-318.

Zachara, BA, Wardak, C, Didkowski, W, Maciag, A \& Marchaluk, E (1993b) Changes in blood selenium and glutathione concentrations and glutathione peroxidase activity in human pregnancy. Gynecol Obstet Invest 35, 12-17.

Zadrozna, M, Gawlik, M, Nowak, B, Marcinek, A, Mrowiec, H, Walas, S, et al. (2009) Antioxidants activities and concentration of selenium, zinc and copper in preterm and IUGR human placentas. J Trace Elem Med Biol 23, 144-148. 


\section{$1110 \quad$ Figure legends}

1111

1112 Figure 1: Selenium metabolic pathway. This diagram illustrates how selenoproteins can

1113 be produced in the body from a variety of selenium sources. Glutathione (GSH) is

1114 considered to be the main component of the selenium metabolism pathway taking part in

1115 the first of a series of reduction reactions which convert selenite to hydrogen selenide

$1116\left(\mathrm{H}_{2} \mathrm{Se}\right)$. [Se]Met: selenomethionine; [Se]Cys: selenocysteine. Adapted from (Sunde,

1117 1990, Ip, 1998, Patrick, 2004).

1118

1119 Figure 2: Major pathways of reactive oxygen species generation and metabolism.

1120 Superoxide can be generated by specialized enzymes, such as the xanthine or NADPH

1121 oxidases, or as a byproduct of cellular metabolism, particularly the mitochondrial electron

1122 transport chain. Superoxide dismutase (SOD) then converts the superoxide to hydrogen

1123 peroxide $\left(\mathrm{H}_{2} \mathrm{O}_{2}\right)$ which has to be rapidly removed from the system. This is generally

1124 achieved by catalase or peroxidases, such as the selenium dependent glutathione

1125 peroxidases (GPxs) which use reduced glutathione (GSH) as the electron donor. 